\title{
Dental management of a child with a rare bone disorder: a case report with a six-year follow up
}

\author{
Manejo odontológico de uma criança com doença óssea rara: \\ relato de caso com acompanhamento de seis anos
}

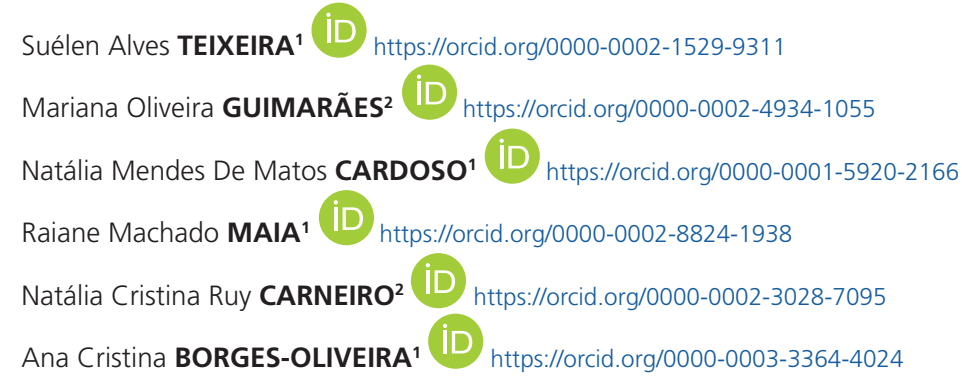

\section{ABSTRACT}

Osteogenesis imperfecta is a rare genetic disorder involving abnormal type I collagen composition that compromises bone and collagenrich tissues. Individuals with Osteogenesis imperfecta exhibit oral and systemic abnormalities, including dentinogenesis imperfect. The purpose of the review is to report a clinical case of a nine-year-old boy diagnosed with Osteogenesis Imperfecta type III, focusing on dental and occlusal aspects. The case report was developed at the outpatient clinic at the School of Dentistry of the Federal University of Minas Gerais, in Southeastern of Brazil. The clinical oral examination revealed Angle Class III malocclusion and anterior crossbite. It was also observed the presence of dentinogenesis imperfect in both primary and permanent teeth. Radiographic analysis showed the presence of completed obliterated pulp chambers in both dentitions. Dental treatment included oral hygiene counseling, dental extraction, fluoride therapy and restorations. The child was followed up for a period of six years and then referred to the orthodontic outpatient clinic at the same university for the treatment of malocclusion. Early dental care is important to the prevention or interception of oral diseases, such as dentinogenesis imperfect and malocclusion, as well as the improvement of dental esthetics in cases of Osteogenesis Imperfecta.

Indexing terms: Oral health. Osteogenesis imperfecta. Rare diseases.

\section{RESUMO}

A Osteogênese imperfeita é uma doença genética rara que ocorre devido à produção anormal de colágeno tipo I, comprometendo os tecidos ósseos e aqueles ricos em colágeno. Os indivíduos com Osteogênese imperfeita apresentam diversas anormalidades na

$\boldsymbol{\nabla} \boldsymbol{\nabla} \nabla$

1 Universidade Federal de Minas Gerais, Faculdade de Odontologia, Departamento de Odontologia Social e Preventiva. Av. Antônio Carlos, 6627, Campus Pampulha, 31270-901, Belo Horizonte, MG, Brasil. E-mail: <su.alvesteixeira@gmail.com>.

2 Universidade Federal de Minas Gerais, Faculdade de Odontologia, Departamento de Saúde Bucal da Criança e do Adolescente. Belo Horizonte, MG, Brasil.

$\nabla \nabla v$

How to cite this article

Teixeira SA, Guimarães MO, Cardoso NMM, Maia RM, Carneiro NCR, Oliveira ACB. Dental management and rare diseases. RGO, Rev Gaúch Odontol. 2020;68:e20200050. http://dx.doi.org/10.1590/1981-863720200005020190074 
cavidade bucal, incluindo a presença de dentinogênese imperfeita. O objetivo do relato de caso foi discutir o manejo odontológico de um menino de nove anos, diagnosticado com Osteogênese Imperfeita tipo III, com enfoque nos aspectos dentários e oclusais. O caso foi desenvolvido em uma das clínicas da Faculdade de Odontologia da Universidade Federal de Minas Gerais, na região sudeste do Brasil. O exame clínico bucal revelou presença de má oclusão de Classe III de Angle, e mordida cruzada anterior. Observou-se também, a presença de dentinogênese imperfeita na dentição decídua e permanente. A análise radiográfica revelou câmaras pulpares completamente obliteradas em ambas as dentições. O tratamento odontológico incluiu orientação de higiene bucal, fluorterapia, exodontias e restaurações. A criança foi acompanhada por um período de seis anos e, em seguida, encaminhada para a clínica de Ortodontia da mesma universidade para o tratamento da má oclusão. O atendimento odontológico precoce é importante para a prevenção ou interceptação de doenças bucais, como a dentinogênese imperfeita e má oclusão, bem como para a melhora da estética dentária nos indivíduos com Osteogênese Imperfeita.

Termos de indexação: Saúde bucal. Osteogênese imperfeita. Doenças raras.

\section{INTRODUCTION}

Osteogenesis imperfecta (OI) is a rare genetic disorder involving abnormal type I collagen composition, specifically the genes COL1A1 and COL1A2, leading to compromised bone and collagen-rich tissues. Individuals with OI present deficient growth (short stature), osteopenia and progressive bone deformities and fractures. Blue sclera, progressive hearing loss and dentofacial abnormalities are also common findings $[1,2]$. The incidence of the disease is one in 10.000 to 20.000 births, with no predilection for sex or race $[3,4]$. In Brazil, it is estimated that there are more than 19.000 individuals with OI [5].

The Sillence classification categorizes OI into four main types [6]. However, there is a considerable variability and complexity in the genotype. Thus, the disease has several clinical manifestations and has therefore been classified into eight to fifteen types $[1-3,7]$. Based on clinical and radiological features, genetic inheritance type and the genes involved, OI is classified as mild, moderate, severe and extremely severe [2].

\section{Diagnosis}

A large number of clinical manifestations are found in $\mathrm{Ol}$ and the confirmation of the diagnosis is mainly based on the medical and family history as well as clinical and radiographic findings. In the prenatal period, the diagnosis can be performed by radiographic studies of the mother's abdomen, ultrasound and a biochemical analysis of the chorionic villus $[2,7]$.

The most important clinical feature is bone frailty, which is common to all types of OI. Blue sclera, dentinogenesis imperfecta (DGI), short stature, scoliosis and bone deformities are also found. Radiographic analysis provides further evaluation of the bone deformities found during the clinical examination and also helps detect the decrease in cancellous bone and thinning of the cortex, especially in the proximal femur $[1-3,6,7]$.

\section{Treatment}

There is no cure for Ol. The treatment consists in therapy with bisphosphonates, which aims to enhance the quality of life of individuals affected [1]. The use of bisphosphonate slows the rate of bone resorption, promoting an increase in bone mass and decreasing bone fragility. It can, consequently, reduce pain and improve mobility [8-10].

However, it is observed that the use of bisphosphonates can cause bone osteonecrosis as a side effect of its administration. In oral cavity, the side effect most observed is the osteonecrosis of the jaw [1, 8-10].

\section{Dental and facial manifestations}

Individuals affected by OI usually have an enlarged, triangular face, small chin and early hearing loss. There is also a tendency towards a class III skeletal pattern, which may be due to maxillary hypoplasia with or without mandibular hyperplasia. The literature describes a high frequency of open bite as well as posterior and/or anterior crossbite in these individuals [1]. The higher prevalence of Angle class III malocclusion may be due to maxillary hypoplasia with or without mandibular hyperplasia $[1,11]$.

DGI is the most prevalent oral alteration in individuals with this disorder, affecting $8.0 \%$ to $100.0 \%$, depending on the type of OI [12-14]. DGI results in defects in the formation of dentin and can be found in both the deciduous and permanent dentition. Affected teeth exhibit discoloration that can be an opalescent grayish, brownish or yellowish hue. DGI is often associated with fractures due to the poor structural support provided by the compromised dentin $[1,11,12,14]$. 
The severity of $D G I$ varies from individual to individual according to the type of OI. The literature reports that individuals who are more severely affected by the disease often develop a more severe dental phenotype [13]. Radiography reveals teeth with constriction in the cervical region, narrow roots and an obliterated pulp chamber due to dentin deposition. Apical radiolucency may also be found due to premature dentin exposure $[14,15]$.

DGI increases the risk of tooth wear, caries and clinical crown fractures $[16,17]$. In teeth affected by DGI, caries progression is slow due to the smaller amount and irregular nature of the dentinal tubules or fast abrasion of the exposed dentin. This attrition can be explained by hypomineralization and lower microhardness of the dentin $[13,18]$. Early treatment prevents significant tooth wear and restores both function and esthetics to the teeth [19]. Treatment involves direct composite restorations, veneers and indirect fabricated composite resin restorations $[1,16,19]$. Primary teeth are usually treated with stainless steel crowns to protect the dental complex and reestablish the vertical dimension [16].

In addition to clinical dental procedures, it is important to manage the behavior cooperation of the patient. Unfortunately, some dentists deny dental care to this part of the population due to a lack of knowledge of the disease or fear of causing a bone fracture $[16,17,19]$.

The aim of the present case report was to discuss the dental management of a child with Ol, focusing on orofacial and occlusal aspects.

\section{CASE REPORT}

The present case report regards the six-year follow up of dental treatment of a nine-year-old boy diagnosed with OI. In 2012 the child (GGOL) was referred by a pediatric orthopaedist from a public outpatient clinic in the city of Belo Horizonte (southeastern Brazil) for dental treatment at the School of Dentistry of the Federal University of Minas Gerais.

According to the mother's report, the child was diagnosed with OI type III during the 28th week of gestation. During the intrauterine period, he had suffered two femur fractures and two tibia fractures. He also suffered about 40 fractures from birth to March 2018. There was no family history of OI or DGI. The child was in treatment with the bisphosphonate pamidronate $(10 \mathrm{mg}$ by intravenous infusion) in 2012. Since the last year he has been in treatment with oral alendronate, which is another type of bisphosphonate.

Trough anamnesis, the patient history revealed that the child had no systemic findings as well as no speech or intellectual problems. He presented with mobility impairment, short stature, a triangular face and a protrusive temporal bone (figure 1).
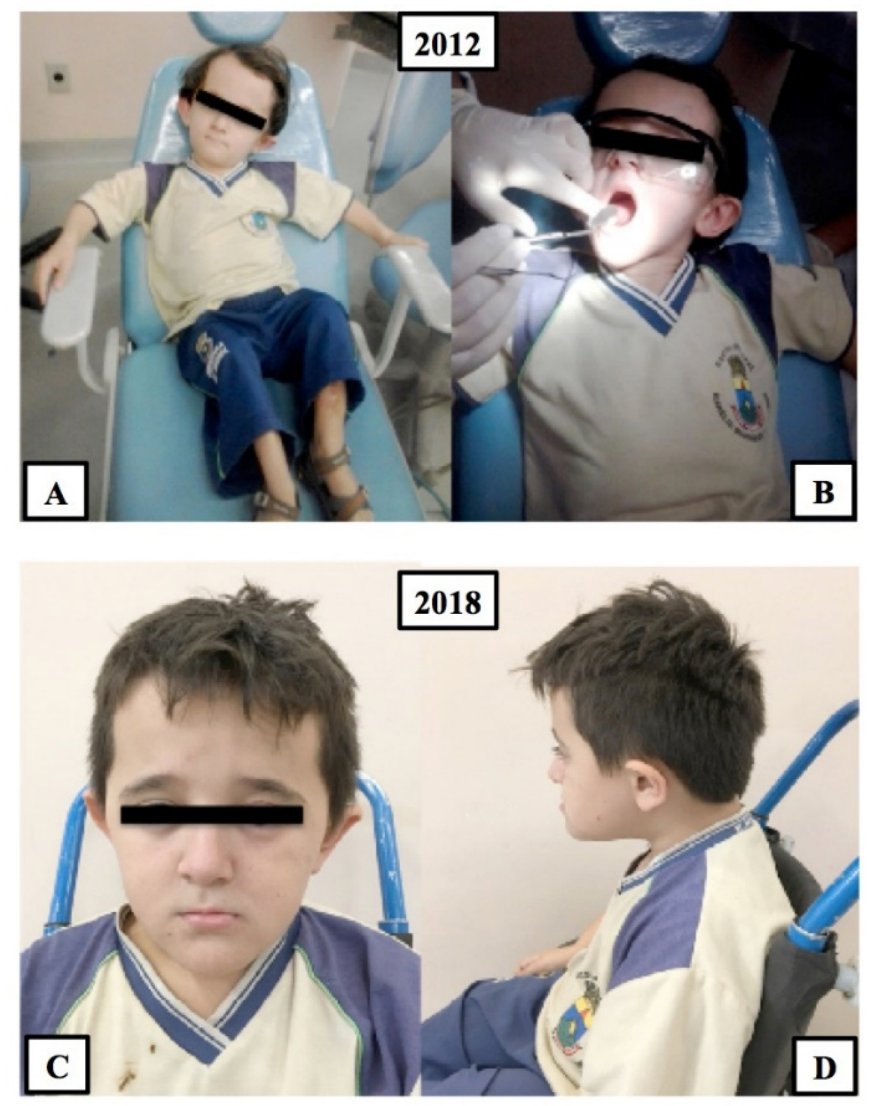

Figure 1. Patient (GGOL) with type III OI in 2012 and 2018. Short stature $(A)$, triangular face ( $B$ and $C$ ), protrusive bitemporal bone $(C)$ and impaired mobility (D).

The clinical oral examination revealed Angle Class III malocclusion and anterior crossbite. DGI was found in both primary and permanent teeth. The teeth were grayish brown in color and had a translucent hue (figure 2). The child was diagnosed with gingivitis and extensive dental caries associated with dentoalveolar abscesses in teeth \#74 and \#54. 

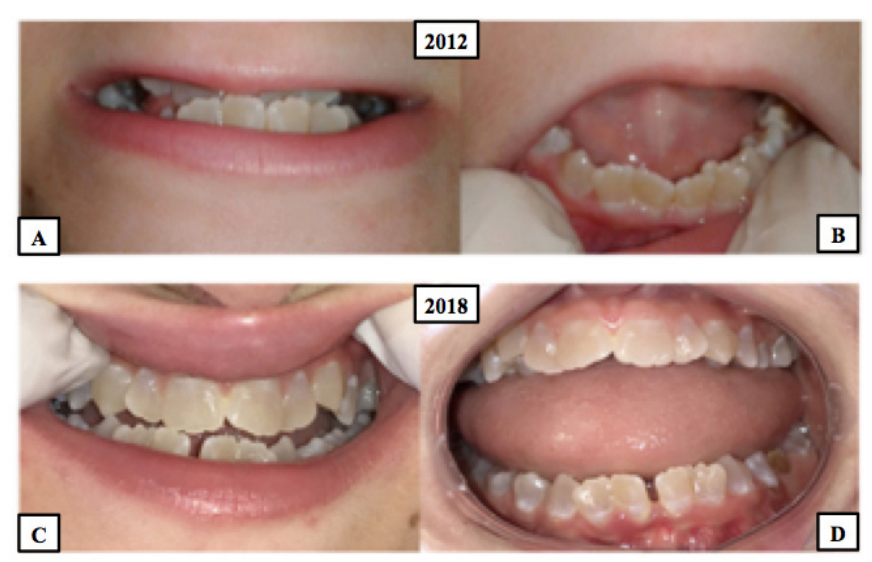

Figure 2. Clinical oral examination showing anterior crossbite and DGI in 2012 ( $A$ and B) and 2018 (C and D).

The radiographic examinations performed in 2012 and 2018 revealed pulp chamber obliteration in both primary and permanent teeth (figure 3 ).
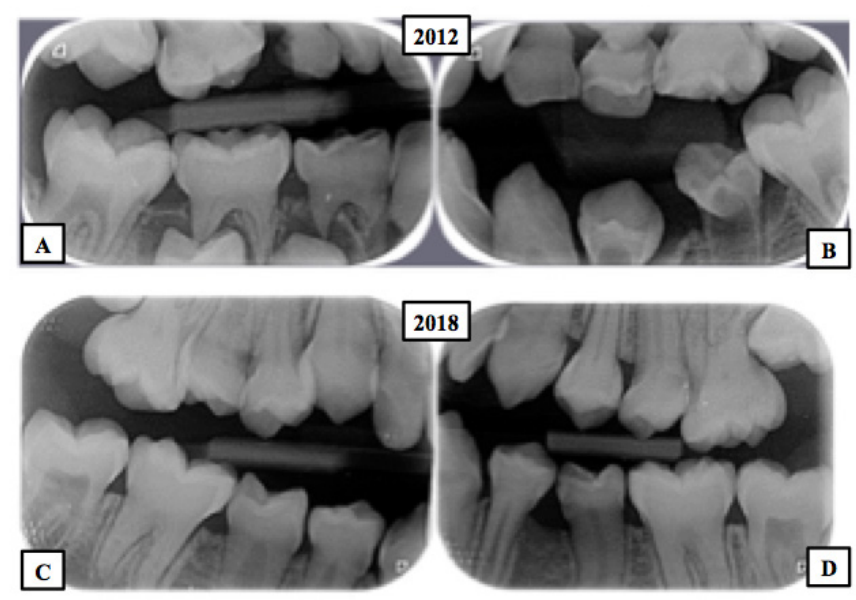

Figure 3. Bitewing radiographs showing teeth with pulp chamber completed obliterated: primary molars in 2012 (A and B); molars and permanent premolars in 2018.

Panoramic radiography performed in 2018 revealed a 1:1 proportion of maxillary incisor crown to root. The complete obliteration of pulp chamber in permanent teeth was also found (figure 4).

In 2012, the treatment plan was organized as prophylaxis, surgical treatment and maintenance phase (follow up). Before the clinical procedures, the clinician managed the child's behavior to ensure cooperation and safe treatment.

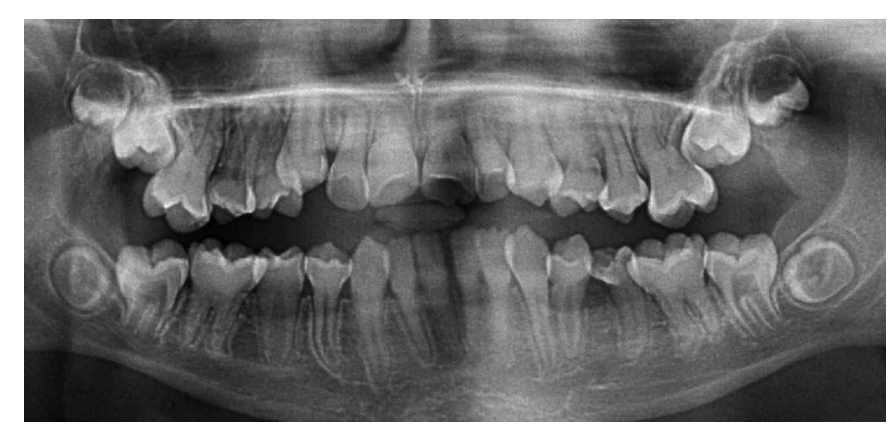

Figure 4. Panoramic radiography showing 1:1 proportion of maxillary incisor crown to root and complete obliteration of pulp chamber in permanent dentition (2018).

Dental plaque was disclosed and demonstrated to the mother and child, and then they were given oral hygiene instructions. The mother under the supervision of a student carried out the teeth's brushing of the child. Topical fluoride was also applied.

The radiographic evaluation involved posterior bitewings and two periapical radiographs (teeth \#74 and \#54). In the second phase, teeth \#74 and \#54 were extracted under local anesthesia using $2 \%$ xylocaine with epinephrine (1:100.000).

Before teeth extraction, the patient was referred to his pediatric orthopaedist to perform a perioperative evaluation and to get necessary medical recommendations. The orthopaedist allowed the procedure and did not discontinue the use of the bisphosphonate. During the dental treatment some care was taken such as: positioning of the child in an adequate and comfortable way in the dental chair, and adequate force of surgical instruments, such as forceps, in order to avoid fractures of the maxillary bones.

After an eight-week postoperative follow-up, it was not observed the presence of osteonecrosis, since there was an adequate healing of the soft tissues around the surgical area.

At the end of all treatment proposed, the mother was instructed to return with the child for a new dental evaluation in six months.

During the next two years of follow up, the patient demonstrated an improvement in oral health, with no gingival inflammation. However, the clinical evaluation performed in November 2014 led to the diagnosis of a non-cavitated carious lesion on the occlusal face of tooth 
\#36 and a cavitated carious lesion on the occlusal face of tooth \#65. Tooth \#36 was treated with an application of fluoride and tooth \#65 was restored with glass ionomer cement (Ketac Molar $®$ ).

In 2018, with permanent dentition completed, it was observed that beyond the presence of Angle class III, the patient presented with a dolichofacial profile, with adequate facial proportionally and passive lip seal. He also presented crowding of the maxillary and mandibular incisors as well posterior and anterior crossbite. Considering the maintenance of good oral health, with the absence of gingival inflammation and dental caries, the patient was referred and scheduled to an outpatient orthodontic clinic at the same institution for an evaluation related to the malocclusion.

\section{DISCUSSION}

There are varying degrees of severity in OI. Bone frailty is severe in type III, which is the type presented by the patient described herein. Type III accounts for $20.0 \%$ of cases of OI $[1,3,6]$ and leads to recurrent bone fractures, with a negative impact on quality of life $[1,20]$.

Individuals with OI require continuous special care, which implies the daily intense dedication of parents/ caregivers. The patient's mother reported visiting several health professionals and hospitals for the treatment of the 40 bone fractures the child had suffered, which demonstrates the effort and commitment on the part of caregivers when dealing with the problems stemming from this disease. The literature describes frequent bone fractures in individuals with type III OI, leading to functional limitations and physical disability due to bone deformities [20].

Considering the health problems and complications associated with rare diseases, such as type III OI, affected individuals require multidisciplinary care with a team formed by an orthopedist, surgeon, physiotherapist, dentist and psychologist $[20,21]$. Although an orthopedist may refer patients to a dental service in some cases, the oral health care of individuals with rare diseases is usually not a priority of many physicians and parents/caregivers in light of the other healthcare needs [21].

The primary molars and permanent teeth in the patient described herein were affected by DGI and were grayish brown in color. DGI in individuals with Ol should be diagnosed as early as possible, as the dentin defect can lead to functional and esthetic problems. The literature reports that although the enamel is normal in teeth with $D G l$, it becomes detached from the histologically modified dentin, leading to dentin exposure. The frequency of $D G l$ in Ol type III is 43.0 to $82.0 \%[13,14,17,18]$.

Radiography of the primary molars revealed completely obliterated pulp chambers. According to the literature, this abnormality is typically observed in DGI type I associated with OI and both primary and permanent teeth can be affected [15].

DGl is considered a risk factor for the development of dental caries, tooth wear and clinical crown fractures $[13,16,17]$. Whenever possible, treatment for this condition should be conservative with the aim of preserving dental structures as well as reestablishing esthetics, function and the vertical dimension. Treatment includes caries prevention, the monitoring of tooth wear, placement of artificial crowns to prevent the excessive loss of the tooth structure and direct bonded restorations [19].

In the present case report, two primary teeth exhibited severe carious lesions with abscesses, requiring extraction. As the child was at the chronological age for the eruption of the permanent teeth (first and second premolars), the extraction of teeth \#54 and \#74 was considered the most appropriate treatment, even in treatment with bisphosphonates [22].

Previous studies stated that the use of bisphosphonates for a long period could be associated to occurrence of osteonecrosis $[8,23,24]$. Osteonecrosis of maxillary bones due to dental extractions bones can be characterized by maxillary or mandibular bone exposure, evidenced by non-healing of soft tissues in the period of eight weeks postoperatively $[8,23]$. However, even though in use of bisphosphonates, it is recommended that dental treatment of compromised tooth with indication of extraction be performed as soon as possible, since not extracting the compromised tooth would lead to the formation and maintenance of infection site in the oral cavity $[8,9,10,24]$.

Direct bonded restoration was also performed due to dental caries on a primary tooth. The patient visited the clinic for follow up to protect the permanent dentition against dental caries and tooth wear. Adhesive materials are not contraindicated in such cases, since adhesive systems and restorative techniques gained progress in recent years. However, the type of procedure to be performed must be 
defined according to the patient's individual characteristics $[16,19]$.

Regarding craniofacial abnormalities in individuals with OI type III, a triangular face, protrusive temporal bone and prominent frontal bone are common findings $[23,25]$. These characteristics seem to be directly related to the degree of bone frailty determined by the molecular abnormalities in collagen synthesis $[25,26]$. The child in the present case report exhibit all the common characteristics of OI type III, the most noticeable of which were the triangular face and protrusive temporal bone.

Craniofacial and dental disorders are more prevalent in individuals with OI type III. Such individuals present a higher prevalence rate of class III malocclusion associated with anterior and posterior open bite. These problems are likely related to the skeletal abnormalities found in the more severe forms of Ol, such as type III $[1,8,23,26]$. In the present case, after dental treatment, oral hygiene counseling and caries control, the child was referred for an orthodontic evaluation.

Most individuals with $\mathrm{Ol}$ are in bisphosphonate therapy, as was the child in this case report [27]. The aim of such treatment is to reduce the risk of associated fractures and inhibit bone resorption, thereby reducing pain intensity and the occurrence of fractures as well as improving mobility $[8,27]$. There is no evidence in the literature to contraindicate orthodontic treatment for individuals in bisphosphonate therapy [28]. The recovery of oral function and esthetics is fundamental to the enhancement of self-esteem and patient satisfaction as well as for a better performance on activities of daily living, leading to an improvement in quality of life $[20,23]$.

There is still a great need to perform additional studies regarding the use of bisphosphonates during orthodontic treatment. According to Consolaro et al., the contraindication of bisphosphonates in orthodontic treatment is based on professional opinion, case reports, and personal experience or experiment trials with failing methods [25]. Regarding orthodontic treatment of Class III, there is also no data in the literature about specific orthopedic protocols for children with OI receiving bisphosphonates therapy [29]. Dentists should keep in touch with the medical team that assist individuals with OI, because in some cases it can be necessary to discontinue the bisphosphonate therapy during active phase of a rapid maxillary expansion [29].
Considering that the presence of OI implies in many oral manifestations in individuals affected, it is important to provide an early and multidisciplinary approach to them. An extended treatment plan adapted to each patient's condition is essential for successful treatment and good oral health maintenance.

\section{CONCLUSION}

Osteogenesis Imperfecta type III is the one with the most severe conditions of bone frailty and is related to oral manifestations, such as Angle class III malloclusion and dentinogenesis imperfecta. Early dental care is important to the prevention or interception of oral diseases, such as dentinogenesis imperfect and malocclusion, as well as the improvement of dental function and esthetics.

\section{Acknowledgements}

This study was financed in part by the Coordenação de Aperfeiçoamento de Pessoal de Nível Superior - Brasil (CAPES) - Finance Code 001; Conselho Nacional de Desenvolvimento Científico e Tecnológico - Brasil (CNPq); Fundação de Amparo à Pesquisa do Estado de Minas Gerais - Brasil (FAPEMIG); and Pró-Reitoria de Pesquisa da Universidade Federal de Minas Gerais (PRPq/UFMG).

\section{Collaborators}

SA TEIXEIRA and MO GUIMARÃES participated in the clinical case conduction and writing of the article. NMM CARDOSO and RM MAIA collaborated in the writing and critical revision of the article. NCR CARNEIRO and ACB OLIVEIRA participated in the clinical case conduction and critical revision of the article.

\section{REFERENCES}

1. Rauch F, Glorieux FH. Osteogenesis imperfecta. Lancet. 2004;9418:1377-1385. http://dx.doi.org/10.1016/S0140-6736 (04)16051-0

2. Van Dijk FS, Sillence DO. Osteogenesis imperfecta: clinical diagnosis, nomenclature and severity assessment. Am J Med Genet A. 2014;164A(6):1470-1481. http://dx.doi.org/10.10 02/ajmg.a.36545

3. Alharbi SA. A systematic overview of osteogenesis imperfecta. Mol Biol. 2016;5:1-9. http://dx.doi.org/10.4172/2168-9547.10 00150 
4. OIFE.org [homepage on the internet]. Osteogenesis Imperfecta Federation Europe [cited 2018 Set 01]. Available from: <http://www.oife.org/index.php/EN>.

5. ABOI.org [homepage on the internet]. Associação Brasileira de Osteogênese Imperfeita [cited 2018 Set 01]. Available from: <www.aboi.org.br>

6. Sillence DO, Senn A, Danks DM. Genetic heterogeneity in osteogenesis imperfecta. J Med Genet. 1979;16(2):101-116.

7. Valadares ER, Carneiro TB, Santos PM, Oliveira AC, Zabel $B$. What is new in genetics and osteogenesis imperfecta classification? J Pediatr. 2014;90(6):536-54. http://dx.doi. org/10.1016/j.jped.2014.05.003

8. Schwartz S, Joseph C, lera D, Vu DD. Bisphosphonates, osteonecrosis, osteogenesis imperfecta and dental extractions: a case series. J Can Dent Assoc. 2008;74(6):537-542.

9. Khan AA, Morrison A, Hanley DA, Felsenberg D, Mccauley LK, Oryan F. Diagnosis and management of osteonecrosis of the jaw: A systematic review and international consensus. J Bone Miner Res. 2015;30(1):3-23. http://dx.doi.org/10.1002/ jbmr.2405

10. Reyes C, Hitz M, Prieto-Alhambra D, Abrahamsen B. Risks and benefits of biphosphonates therapies. J Cel Biochem. 2016;117:20-28. http://dx.doi.org/10.1002/jbc.25266

11. Rios D, Vieira ALF, Tenuta LMA, Machado MAAM. Osteogenesis imperfecta and dentinogenesis imperfecta: associated disorders. Quintessence Int. 2005;36:695-701.

12. Milano MM, Wright T, Loechner KJ. Dental implications of osteogenesis imperfecta: Treatment with IV bisphosphonate: report of a case. Pediatric Dent. 2011;33(4):349-352.

13. Cardoso T, Costa R, Cardoso IL. Dentinogenesis imperfecta: a brief review. Rev Port Estomatol Med Dent Cir Maxilofac. 2011; 52:52-55.

14. Andersson K, Dahllöf G, Lindahl K, Kindmark A, Grigelioniene $\mathrm{G}$, Åström $\mathrm{E}$, et al. Mutations in COL1A1 and COL1A2 and dental aberrations in children and adolescents with osteogenesis imperfecta - A retrospective cohort study. Plos One. 2017;12(5):1-16. http://dx.doi.org/10.1371/journal.pone. 0176466

15. Kawashima N, Okiji T. Odontoblasts: specialized hard-tissueforming cells in the dentin-pulp complex. Congenit Anom (Kyoto). 2016;56(4):144-153. http://dx.doi.org/10.1111/cga. 12169

16. Sanches K, Queiroz AM, Freitas AC, Serrano KVD. Clinical features, dental findings and dental care management in osteogenesis imperfecta. J Clin Pediatr Dent. 2005;30(1):77-82.

17. Muhney K, Campbell PR. Pediatric dental management of a patient with osteogenesis imperfect and dentinogenesis imperfecta. Spec Care Dentist. 2007;27(6):240-245.

18. Teixeira CS, Santos Felippe MC, Tadeu Felippe W, Silva-Sousa $\mathrm{YT}$, Sousa-Neto MD. The role of dentists in diagnosing osteogenesis imperfecta in patients with dentinogenesis imperfecta. J Am Dent Assoc. 2008;139(7):906-14.

19. Beltrame AP, Rosa MM, Noschang RA, Almeida IC. Early rehabilitation of incisors with dentinogenesis imperfecta type II - Case report. J Clin Pediatr Dent. 2017;41(2):112-115. http://dx.doi.org/10.17796/1053-4628-41.2.112

20. Vanz AP, van de Sande Lee J, Pinheiro B, Zambrano M, Brizola E, da Rocha NS, et al. Health-related quality of life of children and adolescents with osteogenesis imperfecta: a cross-sectional study using PedsQL'TM. BMC Pediatr. 2018;18(1):1-6. http:// dx.doi.org/10.1186/s12887-018-1077-z

21. Carneiro NCR, Deps TD, França EC, Valadares ER, Pordeus IA, Borges-Oliveira AC. Oral health of children and adolescents with mucopolysaccharidosis and mother's Sense of Coherence. Spec Care Dentist. 2017;37(5):223-229. http:// dx.doi.org/10.1111/scd.12238

22. Legović $M$, Legović $A$, Slaj $M$, Mestrović S, Lapter-Varga $M$, Slaj M. Teeth eruption in children with normal occlusion and malocclusion. Coll Antropol. 2008;32(5):519-22.

23. Nguyen MS, Binh HD, Nguyen KM. Occlusal features and need for orthodontic treatment in persons with osteogenesis imperfecta. Clin Exp Dent Res. 2017;3(1):19-24. http://dx.doi. org/10.1002/cre2.53

24. Krishnan S, Pandian S, Kumar SA. Effect of bisphosphonates on orthodontic tooth movement-an update. J Clin Diagn Res. 2015;9(4):1-5. http://dx.doi.org/10.7860/JCDR/2015/11 162.5769

25. Jabbour Z, Al-Khateeb A, Eimar H, Retrouvey JM, Rizkallah J, Glorieux FH et al. Genotype and malocclusion in patients with osteogenesis imperfecta. Orthod Craniofac Res. 2018;21(2):71-77. http://dx.doi.org/10.1111/ocr.12218.

26. Waltimo-Sirén J, Kolkka, M, Pynnönen S, Kuurila K, Kaitila I, Kovero O. Craniofacial features in osteogenesis imperfecta: a cephalometric study. Am J Med Genet A. 2005;133A(2):142-150. http://dx.doi.org/10.1002/ajmg.a.30523

27. Gupte T, lyer V, Damle S G, Malik N, Halbe A. Osteogenesis imperfecta. J Indian Soc Pedod Prev Dent. 2006;24, Suppl S1:44-6.

28. Consolaro A. The use of bisphosphonates does not contraindicate orthodontic and other types of treatment. Dental Press J Orthod. 2014;19(4):18-26. http://dx.doi.org/10. 1590/2176-9451

29. lerardo G, Calcagnile F, Luzzi V, Ladniak B, Bossu M, Celli M, et al. Osteogenesis imperfecta and rapid maxillary expansion: report of 3 patients. Am J Orthod Dentofacial Orthop. 2015;148 (1):130-137. http://dx.doi.org/10.1016/j.ajodo.2015. 01.029

Received on: 30/4/2019 Final version resubmitted on: $8 / 8 / 2019$ Approved on: 24/9/2019 